\title{
Calvo Is Back! Changing Sovereignty and Evolutionary Investment Law in a Leaving and Return of the State Paradigm
}

\author{
Shuo Feng ${ }^{*} \&$ Wei Shen ${ }^{* *}$
}

\begin{abstract}
Although the key purpose of international investment law is to promote foreign investor protection by offering both substantive and procedural standards, the international investment governance regime needs to strike a balance between foreign investor rights protection and the host state's right to regulate. The changing balance of this dichotomy shapes a leaving-and-return-of-the-state paradigm which explains and rationalizes an evolutionary development of both substantive and procedural norms and the changing status of sovereignty in international investment law. The "leaving" or "return" of the state paradigm informs us of the role of the state in the context of international investment law. This article makes a normative case for reframing investment and national security within what we call the investment rule of law. Both push for and pull from a liberalization movement are in an attempt to reshape this investment rule of law surrounding the concept of sovereignty, the core of international law.
\end{abstract}

* Research Fellow \& Ph.D. Candidate at East China University of Political Science and Law. LL.B. \& LL.M. (ECUPL). ORCID: https://orcid.org/0000-0003-4435-2123. The author may be contacted at: ecupl_fengshuo@163.com/Address: No. 1575, Wanhangdu Road, Shanghai, P.R. China.

** Corresponding Author. KoGuan Distinguished Professor of Law, Shanghai Jiao Tong University Law School; L. Bates Lea Visiting Professor of Law, Michigan Law School. LL.B. \& LL.M. (ECUPL), LL.M. (Michigan), LL.M. (Cantab), Ph.D. (LSE). ORCID: https://orcid.org/0000-0002-6935-1365. The author may be contacted at: shenwei@sjtu.edu.cn/ Address: No.1954 Huashan Road, Shanghai, P.R. China. The authors thank Thomas Stanton, Carrie Shu Shang and Casey Watters for their comments on an earlier draft of this article and Clara Lewis for her excellent editorial input. Part of the early draft was presented in Michigan Law School's Business Law Series Talks and Xiamen University Law School's International Law Series Talks. The authors are grateful for helpful comments and suggestions made by Congyan Cai, Huiping Chen, Fang Fang, Edward Fox, Adam C. Prichard, Gabriel Rauterberg, the participants in these two workshops. This work was supported by the major projects of the National Social Science Foundation under Grant 20ZDA062 and 19ZDA167. The authors bear sole responsibility for the article.

All the website cited in this article were last visited on October 20, 2020. 


\section{Keywords \\ International investment law, Sovereignty, Calvo Doctrine, Investor Protection, Right to Regulate}

\section{Introduction}

Following the structural transformation of the global economic development model along with global economic liberalization, transnational investment has turned into a vital driving force accelerating the pace of economic globalization. As the trend of de-globalization unfolds, however, the modern international investment law regime is currently undergoing structural changes and has increasingly drawn global attention. Unlike other transnational economic activities such as international trade, international investment not merely concerns the private interests of investors but relates to the economic interests of capital importing and exporting states. Hence, the modern international investment law regime premised on international investment agreements (IIAs) has its main content developed and evolving on the basis of the triangular relationship among host states, home states, and investors and the dual dimensions of public-private. The institutional development and structural constraints of the entire investment governance regime essentially cannot be separated from the dynamic balance among the interests of the three players and the private-public dimensions. ${ }^{1}$

In recent years, there has been a new movement in international investment law along with the transformative changes in global economic growth. ${ }^{2}$ In the article titled, The Return of the State, José E. Alvarez investigated the institutional changes in the field of international investment vis-à-vis some key states represented and led by the United States (US). ${ }^{3}$ Some states are increasingly emphasizing the protection of a host state's sovereignty (in the form of its sovereign right or power to regulate foreign investment activities) in the context of reshaping the modern international investment law regime, labeled as the "return" of the state. ${ }^{4}$ Opposite to this movement was the leaving of the state where the host state imposes various constraints on its

1 Wenhua Shan, From North-South Divide to Private-Public Debate: Revival of the Calvo Doctrine and the Changing Landscape in International Investment Law, 27 Nw J. InT'L L. \& Bus. 664 (2007).

2 M. Sornarajah, Resistance and Change in the International Law on Foreign Investment 4-10 (2015).

J. Alvarez, The Return of the State, 20 MinN. J. INT'L L. 230-1 (2011).

4 Id. 
sovereignty in exchange for better investor protection with the aim of attracting more foreign investment and promoting economic development. ${ }^{5}$

This research is composed of five parts including Introduction and Conclusion. Part two, through the lens of Calvo Doctrine, will reviews the construction process of the modern international investment law regime. This part first illustrates the limitations of customary international law in coordinating international investment interests. With the development of international investment, maximizing the benefits of capital flows needs the "leaving" of the state in investment substantive rules. Meanwhile, the "leaving" of the state also promotes investor-state dispute settlement (ISDS). Part three will address the "return" of the state, a recent change to the course of international investment law. First, states' "return" has become the most vital feature of the ISDS reform in recent years. Second, after the global financial crisis, the anti-liberalization transformation of foreign investment law shows a more pronounced tendency to the "return" of the states. Finally, the goal of international investment law regime also shifts from investor protection to right to regulate, indicating the rise of sovereignty and the return of the Calvo Doctrine. Part four will preliminarily assess the evolutionary process of the modern international investment law regime under the "leaving" and "return" of the state and makes predictions as to the development trend as a whole.

\section{The State's "Leaving" and the Construction of the Modern International Investment Law Regime}

\section{A. Limitations of Customary International Law and the Coordination of Interests in International Investment Law}

States are not immune from the international law discourse when they partake in international investment activities. Sovereignty constitutes the core element of international law and is always the crown of a nation-state. ${ }^{6}$ As early as the eighteenth century, Emer de Vattel, from the standpoint of natural law and by analogy between the state and the individual, pointed out:

See generally S. Strange, The Retreat of The State: The Diffusion of Power in The World Economy 16 (1996).

6 A. Cassese, State: Rise and Decline of the Primary Subjects of the International Law, in THE OXFORD HANDBOOK OF THE History of International Law 51 (B. Fassbender \& A. Peters, eds., 2012). 
Since men are naturally equal, and a perfect equality prevails in their rights and obligations, as equally proceeding from nature-nations composed of men, and considered as so many free persons living together in the state of nature, are naturally equal, and inherit from nature the same obligations and rights. Power or weakness does not in this respect produce any difference. ${ }^{7}$

Therefore, the principle of sovereign equality of states, as a fundamental principle of modern international law, is the basic principle followed by sovereign states in transacting relevant international activities, including investment.

Different from other transnational economic activities, international investment activities are substantially a process in which foreign investors make capital contributions to and participate in the economic construction of the host state. Investment activities are deeply rooted in the host state's existing governance and regulatory regime, touching upon all aspects of the host state's legal and governance regimes. Foreign investors making capital investments in a host state should unquestionably comply with the host state's law while respecting its sovereignty. Thus, where foreign investors invest, how they invest, how investment income is protected and what remedial measures are taken for the damages they may have suffered in this model, all depend on the demands of the host state.

Since customary international law principally coordinates the relations between sovereign states, investors as private actors are not eligible subjects under customary international law. ${ }^{8}$ Early theories of international law highlighted the importance of eligible subjects in international law. The so-called protection of aliens was once a defining feature of international law. It involved mostly Western powers demanding respect for certain minimum standards towards their nationals abroad. It gave rise to a variety of mixed claims commissions notably between the US and Latin American states. It was deeply embedded in imperialist practices and shaped the international law of state responsibility. ${ }^{9}$

Carlos Calvo contended that: "Domestic courts shall be entitled to exclusive jurisdiction over disputes between foreigners and sovereign states, and foreigners should not seek non-local remedies such as diplomatic protection."10 Once put

7 E. de Vattel, The Law of Nations, or, Principles of The Law of Nature, Applied to The Conduct and Affairs of Nations and Sovereigns, With Three Early Essays on The Origin and Nature of Natural law and On Luxury 75 (T. Nugent trans, Liberty Fund, Inc., 2008).

8 R. Roxburgh (ed.), Oppenheim International Law: A Treatise (Vol. I: Peace) 17-8 (reproduced by The Lawbook Exchange, 2005).

9 S. Sucharitkul, State Responsibility and International Liability under International Law, 18 Loy. L.A. INT'L \& ComP. L. 828-31 (1996), https://digitalcommons.law.ggu.edu/cgi/viewcontent.cgi?article=1225\&context=pubs.

10 T. Carbonneau \& M. Mourra, Latin American Investment Treaty Arbitration: The Controversies and Conflicts 8 
forward, this view was recognized and welcomed by Latin American states that had just gained independence and existed as weak states with colonial trauma in the world order, and gradually developed into a regional pattern in this region. Latin American countries were heavily exposed to abuses of diplomatic protection as well as armed intervention and occupation by domestic forces of foreign investors. ${ }^{11}$ Some scholars state: "two concepts of non-intervention and absolute equality of foreigners with nationals are the essence of the Calvo Doctrine." ${ }^{, 2}$ It rejects the imperialist privileges and super-national treatment formerly sought and enjoyed by Western powers and their nationals.

Although the investment disputes settlement via diplomatic protection has eased and changed the host state's absolute control over investment activities under the Calvo Doctrine, economic disputes have in essence risen to the political level for the settlement. As a result, such a highly politicized way of resolving investment disputes not merely increases the costs of dispute settlement, but also fails to meet the requirements of investors. Resulting from the continuous development of international investment law, diplomatic protection, as an important legal rule in customary international law, is weakened in the foreign investment protection regime. ${ }^{13}$ In other words, diplomatic protection is left to supplement relevant institutional arrangements that fail to grant investors access to direct action. It is therefore no surprise to see the ultimate disappearance of the Calvo Doctrine.

\section{B. Maximizing the Benefits of Capital Flows and the "Leaving" of the State}

After the two world wars, states have gradually come to realize that wanton exercise of sovereignty and sovereign interests by resorting to wars or other violent means causes more harm than good. Since the signing of the UN Charter, states have restricted sovereignty to achieve a balance of interests in concluding international treaties, in a bid to achieve sustainable peace and development, which has become the starting point of the "leaving" of states.

The postwar economic recovery required a great deal of financial resources for international investment. On the one hand, developed states, represented by the

(2008).

11 I. Shihata, Towards a Greater Depoliticization of Investment Disputes: The Roles of ICSID and MIGA, 1 ICSID REv. 1 (1986).

12 D. Shea, The Calvo Clause: A Problem of Inter-American and International Law and Diplomacy 19-20 (1955).

13 CMS Gas Transmission Company v. Republic of Argentina, ICSID Case No. ARB/01/8, Decision on Jurisdiction, 945 (July 17, 2003), 7 ICSID REP.17 (2007). 
US, wish to export capital to acquire more revenue, while on the other hand, a large number of developing states are eager to drive their own economic development by attracting foreign capital. However, investors from developed economies are not willing to rashly make capital investments in areas without strong legal protection. The walls of sovereignty are no longer effective protection against the capital movement in a much more integrated global market. ${ }^{14}$ Developed and developing states, albeit divergent in interests and agenda, should make a compromise and have gradually reached a consensus in pursuit of common interests. Consequently, the capital-importing states (host states) have to make promises to give foreign investors various economic benefits and comprehensive protection through bilateral investment treaties (BITs). Meanwhile, the host state has also assigned part of its judicial sovereignty, allowing investors to submit disputes to relevant international agencies instead of local courts or tribunals for settlement when their investment rights are infringed upon and disputes arise, thereby avoiding the risk of being arbitrarily infringed upon in the host state. Since then, the protection of investors' interests has transitioned from a customary law one to a treaty-based one. ${ }^{15}$

After taking the first step of urging the "leaving" of states through treaties, along with increasingly active international investment, developed economies, represented and led by the US, have attached more importance to the role of investment treaties and made compromises in giving consent to arbitration instead of relying upon diplomatic protection in the field of international investment. It has led to a rapid increase in the number of IIAs since the 1980s, and subsequently, an explosive growth of IIA-based investment arbitration cases. There was once a trend that Latin American countries would belong to the ICSID Convention. Ecuador, Paraguay and El Salvador were Contracting States to the ICSID Convention and had entered into several BITs with developed countries. Apart from increasing number, the content of the IIAs also indicates and confirms a trend of the "leaving" of states in both substantive and procedural protection of international investment. Domestically, both developed and developing states liberalized their foreign investment regulations; they instead relied upon the ICSID Convention and ISDS to upgrade and stabilize investment and economic policies. ${ }^{16}$

With respect to substantive rules, for the sake of protecting the interests of the host states, especially the right to regulate, the host state often restricts foreign investment

14 R. Higgins, International Law in a Changing International System, 58 CAMBridge L. J. 82 (1999).

15 F. El-Hosseny, Civil Society in Investment Treaty Arbitration: Status and Prospects 293-6 (2017).

16 S. Puig, Emergence \& Dynamism in International Organizations: ICSID, Investor-State Arbitration \& International Investment Law, 44 GEO. J. INT'L L. 570-1(2013). 
premised on its sovereignty, which, as a result, has increased the political risk of investment. Hence, in the treaty model, various states have gradually changed their positions of diplomatic protection and state intervention based on state sovereignty under customary international law. ${ }^{17}$ Rather, they established national treatment and most-favored-nation (MFN) treatment and extended these non-discriminatory standards to the pre-entry stage of investment through BITs for the purpose of protecting foreign investors provided that the status and standards accorded by the host state to investors are not lower than those of their own nationals and other thirdstate nationals. ${ }^{18}$ Apart from the host state's macro commitment to grant national treatment and MFN treatment to foreign investors, BITs have also established standards for protecting the substantive and procedural rights of foreign investors, of which the compensation clause lies at the core. ${ }^{19}$

In the postwar period, foreign investors were most afraid of expropriation or nationalization of investors' property by the host government. This was the main source of investment disputes between the investors and the host states. Early in 1938, the then US Secretary of State Cordell Hull put forward the "Hull Formula" concerning the compensation standard for the expropriation of foreign investors' property when the US investor's property in Mexico was expropriated by the Mexican government. ${ }^{20}$ The Hull Formula required the host state to "timely, fully and effectively" compensate the losses suffered by the foreign investor from the expropriation. ${ }^{21}$ In this case, the host state should compensate the foreign investor promptly, or within a reasonable period of time, and fully for the losses caused by the expropriation, while the compensation must be made in "hard currency" that can be allowed to flow out of the expropriating state freely. ${ }^{22}$

Against this background, the Hull standards have gradually been referred to by or included in more BITs. As José E. Alvarez points out, in establishing the international investment treaty regime in the 1980s, the US gradually raised the protection standards for investors. The 1984 and 1987 US Model BITs not only emphasized the Hull standard on the issue of expropriation and compensation, but extended the standard as a core principle to other aspects of BITs, which has severely

\footnotetext{
7 M. Sornarajah, The International Law on Foreign InVestment 358-60 (2010).

18 Id.

19 Alvarez, supra note 3, at 231-2.

20 P. Del Duca, The Rule of Law: Mexico's Approach to Expropriation Disputes in the Face of Investment Globalization, 51 UCLA L. REv. 118 (2003).

21 G. Hackworth, US Department of State, Pub. No. 1708, (1942) 3 Digest of United States Practice in International LAW 655 (1942).

22 Id.
} 
restricted the sovereignty of the host state and substantially encouraged the "leaving" of states. ${ }^{23}$

\section{C. "Leaving" of the States and the ISDS}

The ISDS regime has, to a certain extent, achieved a new equilibrium between the jurisdiction of domestic courts and the settlement mechanism for international investment disputes given the fact that it has selectively ensured the minimum level of respect for state sovereignty and the minimum protection for the interests of foreign investors in a balanced manner within a limited boundary. States that are part of this IIA regime also recognize and share the mutual benefits of this regime. ${ }^{24}$ The traditional investment dispute settlement mechanism premised on state sovereignty and diplomatic protection is too often tainted by strong political intervention by home states in defense of their investors, rendering it difficult to directly and effectively resolve disputes, and impossible to satisfy investors' demands for better and effective rights protection. ${ }^{25}$

The Calvo Doctrine has also proved to be an inadequate response to the needs of developing countries whose primary policy target is to attract foreign investment and promote economic growth and social development. Therefore, the modernization and liberalization of the settlement mechanism for international investment disputes is a neo-liberalist process of depoliticization and de-centralization of the states in the dispute settlement process. $^{26}$

From the perspective of depoliticization, the settlement of investment disputes has been transformed from politically appealing but counterproductive diplomatic protection to a treaty-based and non-domestic judiciary-centered regime by both: directly prescribing the settlement of investment disputes in treaties and subjecting the sovereignty of the host state to non-political fora. Considering the content, granting foreign investors the right to directly sue the host state has essentially limited or even deprived the host state of its jurisdiction over disputes. ICSID has taken over the sovereignty assigned by the host states and formed a set of multilateral regimes covering dispute settlement and enforcement of investment arbitration

23 Alvarez, supra note 3, at 231-2.

24 R. Popova, Sarei v. Rio Tinto and the Exhaustion of Local Remedies Rule in the Context of the Alien Tort Claims Act: Short-Term Justice, but at What Cost, 28 Hamline J. PuB. L. \& PoL'y 529 (2007).

25 J. Salacuse, The Law of Investment Treaties 358-9 (2010).

26 I. Shihata, Towards a Greater Depoliticization of Investment Disputes: The Roles of ICSID and MIGA, 1 ICSID REV. 24-5 (1986). 
awards. $^{27}$

The investment dispute settlement mechanism established on the basis of BITs and more recent Free Trade Agreements (FTAs), a type of new international legal instrument, does not abandon the other dispute settlement methods in customary international law. For instance, the host state's courts have not been completely excluded from the settlement of investment disputes ${ }^{28}$ since BITs also grant the host state the right to limit disputes that can be submitted to the ICSID for arbitration. Accordingly, the host state is allowed to require investors to resolve investment disputes before local courts, a partial exhaustion of local remedies as well as constraining the home state from exercising their rights of diplomatic protection. Given the opt-in nature of the ISDS system as lex fori, Latin American countries gradually changed their reluctant attitudes and started to join the ICSID in the 1980s, which coincided with efforts by developing countries to promote their interests through a proposal for a new agenda covering a wide range of trade, investment, finance, natural resources issues under the auspices of so-called New International Economic Order in the 1980s. ${ }^{29}$

There are two ways of defining the nature of the ICSID Convention in the context of the leaving or return of sovereign states. It is an institutional structure placed in the middle of a spectrum, as indicated in Chart 1 below, with the Calvo Doctrine on the one extreme representing the maximum protection of the host state's interest, and diplomatic protection on the other extreme, maximizing the sovereignty and interest of the home state of foreign investors. In between these two extremes is a compromise of the sovereignty and interests of both home and host states of foreign investment. ${ }^{30}$ The ICSID system pays considerable attention to the Calvo Doctrine by allowing for the exhaustion of local remedies in the host state (as a condition to its consent to ICSID arbitration) ${ }^{31}$ and for the application of the domestic law of the host state $^{32}$ which can be agreed upon by the host state and codified in its BITs.

27 P. Gilbert, Sovereignty and Tragedy in Contemporary Critiques of Investor State Dispute Settlement, 6 London Rev. INT'L L. 211-6 (2018).

28 J. Alvarez, A BIT on Custom, 42 N.Y.U. J. INT'L L. \& PoL. 72 (2009).

29 Declaration on the Establishment of a New International Economic Order, G.A. Res. 3201, (VI) U.N. GAOR, 29th Sess., Supp. No.1, U.N. Doc. A/Res/3201(VI) (May 1, 1974).

30 J. Barker, The Protection of Diplomatic Personnel 64-5 (2006).

31 ICSID Convention art. 26.

32 Id. art. 42. 
Chart 1: Spectrum of Sovereignty in ISDS

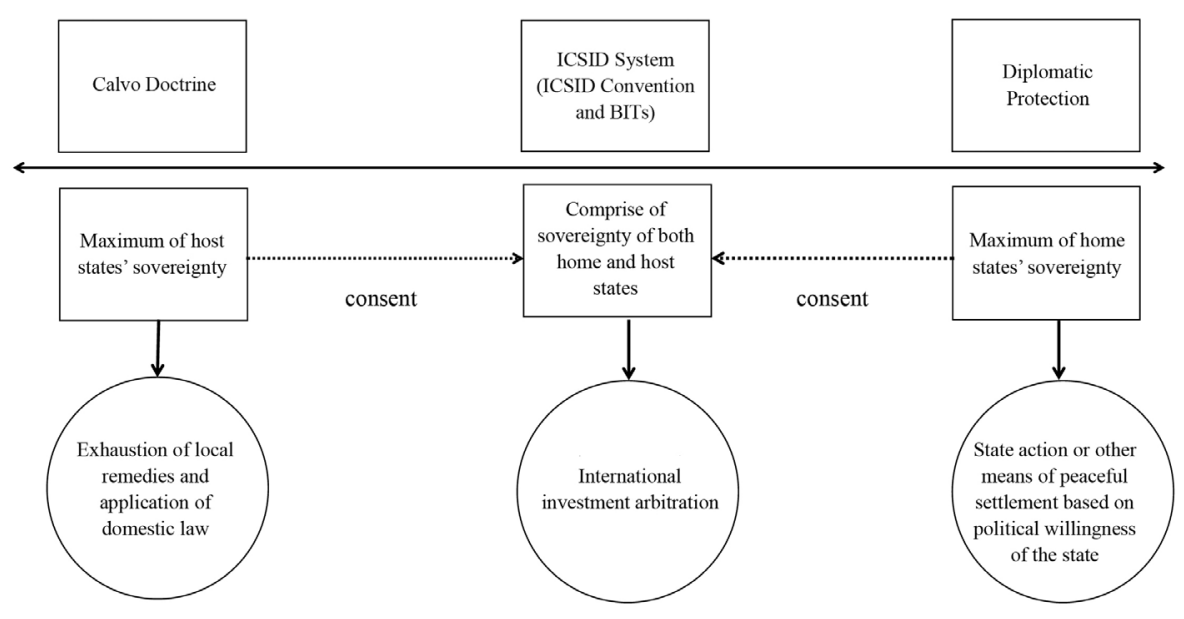

* Compiled by the authors.

Meanwhile, the exclusivity of the ICSID system, as an alternative mechanism built upon the ICSID Convention and BITs, disallows the investor from asking their home state to espouse their case and prohibits the home state from giving diplomatic protection or bringing an international claim with respect to a dispute because its national and the host state have consented to submit to the ICSID arbitration. Therefore, the host state's consent (showing its own agreement to dilute sovereignty) under the BIT guarantees the foreign investor access to a neutral international forum for enforcing the host state's treaty obligations and precludes the home state from intervening in the dispute via diplomatic protection. Essentially, the ISDS system, as lex fori for investment disputes, sidestepped clashes between developing and developed states over the limits or excesses of sovereignty as competing frameworks to resolve conflicts involving foreign investors. ${ }^{33}$

The second layer of significance attached to the ICSID system, in brief, is its representation of the "leaving" of both home and host states in the investment dispute settlement mechanism. ICSID and its affiliated ISDS system, as a means of de-politicizing investment disputes, have been gradually accepted by Latin American countries previously indifferent or opposed to ICSID. ${ }^{34}$ Framing the ICSID as a minimalistic enterprise of the World Bank and an investment dispute settlement

33 J. Thaliath, Bilateral Investment Treaties and Sovereignty: An Analysis with Respect to International Investment Law, 5 Christ U. L. J. 3-5 (2016).

34 K. Gomez, Latin America and ICSID: David versus Goliath, L. \& Bus. Rev. Am. 213-21 (2011). 
forum served to limit power abuses traditionally observed with the practice of diplomatic protection and reluctance or even hostility towards international rule of law for stronger rights protection to foreign investors. ${ }^{35}$

Although closing a gap between developed and developing states, there still exist differences in the degree of "leaving" due to discrepancies in the interests of countries and the level of the rule of law. Hence, the investment dispute settlement provisions in BITs is not merely a vital indicator that could be relied upon for the evaluation of a state's level/degree of "leaving" and "return," but also a mechanism choice of governance regime-either politicized diplomatic protection or rule-based ISDS. Given the dynamic equilibrium between the home and host states as well as between the Calvo Doctrine and diplomatic protection in terms of their popularity and utility in the global governance system, the state's "return" is destined to come back at a certain point. ${ }^{36}$

\section{The "Return" of the States and the Path of International Investment Law}

\section{A. Imbalanced Interests and the Host States' Dissatisfaction with the ICSID Arbitration}

\section{ICSID's Efficient Operations}

The ICSID arbitration regime based on the ICSID Convention is a vital component for maintaining the operation of the modern international investment law regime. ICSID has become operationally inefficient, triggering a wide range of criticisms and suspicions. Judging from the recent development of the ICSID arbitration, a large number of cases illustrate that the arbitral tribunals restrict the power of the host state and protect investors excessively when they were called upon to interpret and apply treaty terms. As pointed out by commentators, investment arbitration awards accorded greater protection to foreign investment than many realized was possible. ${ }^{37}$

For instance, with regard to the application of the host state's law by the arbitration tribunal, Article 42, Paragraph 1 of the ICSID Convention stipulates that:

\footnotetext{
35 S. Franck, The ICSID Effect? Considering Potential Variations in Arbitration Awards, 51 VA. J. InT'L L. 837 (2011).

36 Jiawen Cui, Global Investment Governance: A Call for Greater System Diversity and Rule Uniformity, 11 BEIJNG L. REv. 621 (2020).

37 V. Lowe, Regulation or Expropriation?, 55 Current Legal Prob. 456 (2002).
} 
"The Tribunal shall decide a dispute in accordance with such rules of law as may be agreed by the parties. In the absence of such agreement, the Tribunal shall apply the law of the Contracting State party to the dispute (including its rules on the conflict of laws) and such rules of international law as may be applicable." [Emphasis added] In accordance with this provision, the applicable law can be determined in two scenarios. First, in the case that the parties have chosen the applicable law, the arbitration tribunal shall apply the law as chosen by the parties. Second, when the parties do not choose the applicable law, the arbitration tribunal shall apply the laws of one of the contracting states and the rules of international law to the dispute. ${ }^{38}$

A closer examination shows the following points worth discussing in the interpretation and application of this provision. In the first case, the so-called "possible consent" essentially gives the arbitration tribunal a greater presumption right. Since the "legal rules" are too abstract, they provide the arbitration tribunal with more discretion in exercising the presumption right, and the arbitration tribunal can infer the above implied agreement from various events and specific cases associated with the parties. ${ }^{39}$ In the second case, since the ICSID Convention does not prioritize the choices of applicable law, the arbitration tribunal can choose the applicable law at will. As the compulsory application of the host state's law is not required, it creates the possibilities for the alternative application of law by arbitration tribunals. ${ }^{40}$

The main methods adopted in these analyses are as follows. First, international law is used to exclude the application of the host state's domestic law. In the case of Wena Hotels v. Egypt, the arbitration tribunal once pointed out that the ICSID Convention does not limit the scope of application of the host state's law and international law (including BITs), so that the arbitration tribunal is entitled to decide on the specific applicable law. ${ }^{41}$ In the case of ADC Affiliate v. Hungary, facing the BIT's explicit agreement to apply the host state's law to the calculation of compensation for expropriation, the arbitration tribunal directly excluded the application of the host state's law to other disputed matters, emphasizing its position that international law shall be applied preferentially except for special agreements in

38 W. Reisman \& M. Arsanjani, Applicable Law under the ICSID Convention: The Tortured History of the Interpretation of Article 42, in Building International Investment Law: The First 50 Years of ICSID 10-1 (M. Kinnear et al. eds., 2015).

39 ICSID, Documents concerning the Origin and Formulation of the Convention 1968, 939.

40 E. Gaillard \& Y. Banifatemi, The Meaning of "and" in Article 42(1), Second Sentence of the ICSID Convention: The Role of International Law in the ICSID Choice of Law Process, 18 ICSID Rev. 399-411 (2003).

41 Wena Hotels Ltd. v. Arab Republic of Egypt, ICSID Case No. ARB/98/4, Decision, ๆ (Dec. 8, 2000), 6 ICSID Rep. 939 (2002). 
the BIT. ${ }^{42}$ Second, the influence of the host state's law is diluted by its combination with international law. In the case of Antoine v. Burundi, the arbitration tribunal recognized that excessive restrictions on the host state's law will lead to an imbalance of interests in the investment arbitration regime. ${ }^{43}$ Therefore, when settling disputes, the host state's law and international law are often combined to be used to deal with the cases. In this process, in applying the host state's domestic law at the parties' choice, the arbitration tribunal emphasized the supplementary, corrective and even restrictive function of international law. ${ }^{44}$

This tendency to exclude and restrict the application of the host state's law has occurred frequently in the ICSID arbitration practices in recent years. In the case of Kim and others $v$. Uzbekistan, when the host state interpreted the BIT in accordance with the Vienna Convention on the Law of Treaties (VCLT) to prove that when investors violate the laws of that state and raised objections to jurisdiction, the arbitration tribunal, while demonstrating the applicability of $\mathrm{VCLT}^{45}$ still rejected the host state's defense on the vague ground that investors had conducted investment activities in accordance with the host state's law and did not seriously damage the interests of the host state, deliberately avoiding the application of the host state's law. ${ }^{46}$ Although Philippe Sands, the arbitrator in this case, held in a dissenting opinion that the host state's law should be considered and applied in combination with relevant international laws ${ }^{47}$ based on the opinions of the arbitration tribunal in the case of Urbaser v. Argentina, ${ }^{48}$ this view was not supported or adopted by other arbitrators finally. In the case of Bear Creek Mining v. Peru, the host state proposed that the host

42 ADC Affiliate Limited and ADC \& ADMC Management Limited v. The Republic of Hungary, ICSID Case No. ARB/03/16, Award, Oct. 2, 2006, $\uparrow$ ๆ 288-293, https://www.italaw.com/sites/default/files/case-documents/ita0006.pdf.

43 Antoine Goetz and others v. Republic of Burundi, ICSID Case No. ARB/95/3, Award, Feb. 10, 1999, ๆ 98, https:// www.italaw.com/sites/default/files/case-documents/ita0380.pdf.

44 Hongrui Chen, The Application of Host State's Law in International Investment Arbitration: The Acceptability of Article 30 of US Model BIT [论东道国法律在国际投资仲裁中的适用-兼评2004年美国BIT范本第30条的可接受性], J. INT'L ECON. L. [国际经济法学刊] 162-7 (2010).

45 The Vienna Convention on the Law of Treaties, adopted and opened for signature on May 23, 1969, entered into force January 27, 1980 (1155 U.N.T.S. 331) was acceded to by Kazakhstan on January 5, 1994 and by Uzbekistan on July $12,1995$.

46 Pavel Borissov, Aibar Burkitbayev, Almas Chukin and others v. Republic of Uzbekistan, ICSID Case No. ARB/13/6, Decision on Jurisdiction, Mar. 8, 2017, 9413,541 , https:/www.italaw.com/sites/default/files/case-documents/italaw 8549.pdf.

47 Pavel Borissov, Aibar Burkitbayev, Almas Chukin and others v. Republic of Uzbekistan, ICSID Case No.ARB/13/6, Partial Dissenting Opinion Professor Philippe Sands, Mar. 8, 2017, $₫ 10$, https://www.italaw.com/sites/default/files/ case-documents/italaw8549.pdf.

48 Urbaser S.A. and Consorcio de Aguas Bilbao Bizkaia, Bilbao Biskaia Ur Partuergoa v. The Argentine Republic, ICSID Case No. ARB/07/26, Award, Dec. 8, 2016, ๆ 1199, https://www.italaw.com/sites/default/files/case-documents/ italaw8136_1.pdf. 
state's local law should be treated differently from international law. However, the arbitration tribunal rejected this view. ${ }^{49}$ Therefore, in ICSID arbitrations, even if the ICSID Convention and BITs both stipulate that the host state's law can be applied, the arbitration tribunal could possibly evade the application of the host state's law. Even if the host state's law has to be applied, other methods have often been employed to control the influence of the host state's law to a minimum level. ${ }^{50}$

As a result of vague substantive terms in a large number of BITs, the inconsistent interpretative techniques applied by a large number of arbitration tribunals probably with the pre-set objective of offering better rights protection to foreign investors as well as the lack of independence of ISDS owing to a close-knit community of party-appointed international arbitrators, ${ }^{51}$ the ISDS system left varying negative impressions to the users and commentators. Some cases may have indicated a tendency that investors from wealthy states were equipped with more power over the governments of less wealthy host states, while other cases may have justified the existence and utility of ISDS as a tool of protecting foreign investors from opportunistic actions like expropriations in host states without strong rule of law and legal institutions. ${ }^{52}$

Consequently, both accusations may be in existence simultaneously. In this regard, weak or poor host states are fighting large multinational companies, while private entities are fighting arbitrary actions taken by developing states. Increasing public disapproval has shaken public confidence in ISDS and caused outcry.

\section{Developing States' Withdrawal from the ICSID}

It is precisely the excessive investor protection in the ICSID arbitration that causes more states' dissatisfaction with this regime. In light of relevant statistics, over the past thirty years, Latin American states, represented by Argentina have been among the top respondent states in the ICSID arbitration cases. ${ }^{53}$ The large-amount of compensation arising from investment arbitration cases became a vital factor affecting these countries' economic development. Since 2007, Bolivia, Ecuador, Venezuela, and other states have announced their decisions to withdraw from the ICSID Convention.

49 Bear Creek Mining Corporation v. Republic of Peru, ICSID Case No. ARB/14/21, Award, Nov. 30, 2017, $\uparrow \uparrow$ 267-269, https:/www.italaw.com/sites/default/files/case-documents/italaw9381.pdf.

50 G. Elombi, ICSID Awards and the Denial of Host State Laws. 11 J. InT'L Arb. 67-8 (1994).

51 S. Karamanian, International Decision, Compania de Aguas del Aconquija S.A. \& Vivendi Universal S.A. v Argentine Republic, 105 Ам. J. INT’L L. 555 (2011).

52 G. Kahale II., Rethinking ISDS, 44 Brook. J. InT’L L. 12-20 (2018).

53 UNCTAD statistics show that Argentina has been indicted 62 times in ICSID, ranking first in ICSID, https:// investmentpolicy.unctad.org/investment-dispute-settlement?id=8\&name=argentina\&role=respondent. 
Argentina was to reconsider its participation in the regime because more than sixty arbitration cases have dragged down its economic development. ${ }^{54}$

There has been a domino effect in Latin America. After having entered 23 BITs, Bolivia denounced the ICSID Convention in 2007. After the new Constitution of Bolivia was enacted in 2009, the government announced its plan to denounce and renegotiate the existing BITs as they were deemed to be contrary to the new Constitution. Ecuador's denunciation was notified in July 2009 and came into effect in January $2010 .^{55}$

Venezuela announced its withdrawal in January 2012 which became effective in July 2012. The Foreign Ministry's 2012 press-release points out that the country acceded to the ICSID Convention in 1993 by "a decision of a provisional and weak government, devoid of popular legitimacy, and under the pressure of transnational economic sectors involved in the dismantling of Venezuela's national sovereignty." ${ }^{, 26}$

As of May 2013, Latin American countries were parties in 81 out of 262 cases concluded (approximately 31\%). Of the 167 cases still pending, 73 of them were against Latin American countries (approximately 44\%). ${ }^{57}$ Argentina alone had 25 cases before ICSID, passed a draft bill dated March 21, 2012, and then indicated its plan to exit. $^{58}$

Withdrawals from ICSID by Bolivia, Ecuador, Venezuela and Argentina, and their termination of BITs ${ }^{59}$ are not only a radical expression of these countries' dissatisfaction with the ICSID Convention's regime, but also a dramatic portrayal of a broader trend to revisit key aspects of international investment law. The exit from the ICSID Convention and the global forum for the settlement of investment disputes signals these countries' loss of faith in the ISDS system. Although the withdrawal from the ICSID Convention does not entirely block the future international investment arbitration against these countries, denouncing the ICSID Convention

54 C. Goodman, Uncharted Waters: Financial Crisis and Enforcement of ICSID Awards in Argentina, 28 U. PA. J. INT'L ECON. L. 483 (2007).

55 S. Fiezzoni1, The Challenge of UNASUR Member Countries to Replace ICSID Arbitration, 2 BeIJng L. Rev. 135-6 (2011).

56 S. Ripinsky, Venezuela's Withdrawal from ICSID: What it Does and Does Not Achieve, Apr. 13, 2012, https://www. iisd.org/itn/2012/04/13/venezuelas-withdrawal-from-icsid-what-it-does-and-does-not-achieve/\#_ftn2.

57 N. Beoglin, ICSID and Latin America: criticisms. Withdrawals and Regional Alternatives, July 4, 2013, http://www. cadtm.org/ICSID-and-Latin-America-criticisms.

58 Bill of Argentina Congress dates April 21, 2012. See Text of the draft of that bill, http://www1.hcdn.gov.ar/proyxml/ expediente.asp?fundamentos $=$ si\&numexp=1311-D-2012.

59 In 2008, Ecuador terminated nine BITs-with Cuba, the Dominican Republic, El Salvador, Guatemala, Honduras, Nicaragua, Paraguay, Romania and Uruguay, https://www.iisd.org/itn/2017/06/12/ecuador-denounces-its-remaining16-bits-and-publishes-caitisa-audit-report. 
does send a political message to show state refusal of future cooperation in the regime, and more realistically, the lack of likelihood of the collection of damages ordered by ICSID tribunals against these countries. ${ }^{60}$

Some scholars therefore pointed out that the Calvo Doctrine, which was once popular in Latin American states, has not died out and is possible to revive to be used as resistance in a mildly radical way. ${ }^{61}$ In this sense, the Calvo Doctrine still has value in contemporary international law even though ICSID is said to be a superior solution to the Calvo Doctrine. While the ICSID in its operation indicated its mechanical or even institutional defects as an arbitration machinery and an instrument of international public policy, ${ }^{62}$ the Calvo Doctrine has emerged as a vital institutional source and theoretical basis for the "return" of developing states in the field of international investment. ${ }^{63}$

Apart from the revival of the Calvo Doctrine and the withdrawal of many Latin American states from the ICSID regime, emerging economies as non-parties to ICSID such as India, Brazil and South Africa, ${ }^{64}$ which have become increasingly crucial in the field of international investment in recent years, also restrict or even exclude the use of the ISDS regime by updating their model BITs and amending their domestic laws. ${ }^{65}$ The decline or rise of the Calvo Doctrine suggests the "leaving" or "return" of the state when it comes to settling its disputes with foreign investors. The changing role of the Calvo Doctrine indicates the uncertainty of its application which is likely related to the host state's view over its sovereignty. Nevertheless, the principle of diplomatic protection remains part of the realities of international life. ${ }^{66}$

For example, India's model BIT published in 2016 contains full restrictions on the ISDS mechanism. On the one hand, the model BIT highly emphasizes the local remedies such as administrative and judicial tribunals that foreign investors have to resort to in resolving investment disputes with the Indian Government after their

60 N. Kownacki, Prospects for ICSID Arbitration in Post-Denunciation Countries: An Updated Approach, 15 UCLA J. INT'L L. \& Foreign AfF. 559-60 (2010).

61 Wenhua Shan, Is Calvo Dead?, 55 Am. J. Comp. L. 163 (2007).

62 ICSID, Annual Report (1984), at 5, https://icsid.worldbank.org/sites/default/files/publications/annual-report/en/1984ar-final-en.pdf.

63 B. Cremades, Resurgence of the Calvo Doctrine in Latin America, 7 Bus. L. INT'L 57 (2006).

64 By the end of January 2019, India, Brazil and South Africa had not joined ICSID. See ICSID, About ICSID: Member States, https://icsid.worldbank.org/en/Pages/about/Member-States.aspx.

65 S. Rolland, The Return of State Remedies in Investor-State Dispute Settlement: Trends in Developing Countries, 49 Loy. U. CHI. L. J. 395-9 (2017).

66 I. Shihata, Towards a Greater Depoliticization of Investment Disputes: The Roles of ICSID and MIGA, 1 ICSID REv. 3 (1986). 
rights are damaged. ${ }^{67}$ Meanwhile, India believes that the international arbitration tribunal has no right to review the judicial decisions of sovereign states, thus denying international agencies' right to review the decisions of their own courts. ${ }^{68}$ For another example, Brazil signed a number of BITs as early as the 1990s. However, its legislative authority did not approve these BITs in order to safeguard its right to regulate foreign capital. Brazil showed no interest in ratifying the ICSID or any BIT despite having signed some BITs and even though Brazil named the ICSID Secretary-General the "appointing authority" of arbitrators in some guarantee agreements executed by Brazil in favor of foreign lenders to Brazilian public entities. ${ }^{69}$

\section{Developed States' Rising Opposition to the ISDS}

Apart from the challenges raised by developing states towards ISDS, developed states represented by the US and the member states of the European Union (EU) have also joined the ranks of opposing the current ISDS regime. As the world's major capital exporting state, the US has long played the role of the largest home state of claimants in the ICSID arbitration. ${ }^{70}$ Nevertheless, the US has also come to recognize the legal risks of ISDS. In March 2018, the US Trade Representative Robert Lighthizer testified before US Congress and highlighted the reasons why the US Government opposes the inclusion of the mandatory ISDS clauses in the NAFTA renegotiation. He addressed that it would severely damage the American national sovereignty and put the US at great legal risks. ${ }^{71}$ In the meantime, ISDS has also been criticized by many parties, and the US does not have to continue to cheer for the regime. ${ }^{72}$ Similarly, in the Comprehensive and Progressive Agreement for Trans-Pacific Partnership (CPTPP) reached by eleven Pacific states including Canada, Japan, Australia, and others in February 2018, New Zealand, Canada and Chile explicitly excluded the settlement of investment disputes with investors from specific states through ISDS by way of having explicit appendices.

After the Treaty of Lisbon was passed, the power of the EU member states to sign BITs was exclusively possessed and controlled by the European Commission, which also began to reassess the ISDS system and responded to the reform of the modern

\footnotetext{
2016 Model Text for the Indian Bilateral Investment Treaty, art. 15.1, 15.2, 15.4 \& 15.5.

68 Id. art. 13.5 .

69 F. Delaume, ICSID and the Banker, 2 InT'L Fin. L. Rev. 13 (1983).

70 UNCTAD, World Investment Report 2018, at 93, https://unctad.org/en/PublicationsLibrary/wir2018_en.pdf.

71 See Brady-Lighthizer ISDS Exchange, International Economic Law and Policy Blog, Mar. 21, 2018, https:// worldtradelaw.typepad.com/ielpblog/2018/03/brady-lighthizer-isds-exchange.html. 
international investment law regime. ${ }^{73}$

The EU has been calling for the reform of ISDS in recent years, especially in the relevant discussions organized by the United Nations Commission on International Trade and Law (UNCITRAL), clearly pointing out the main problems of the ISDS regime as follows. First, there is a lack of consistency in the interpretation and application of a series of provisions. Second, arbitration tribunals have consistently shown a selective contempt for the sovereign matters of the host states in their longterm investment arbitration practice and have failed to effectively grasp the scale of protection. Third, the lack of a necessary appeal regime makes ISDS lose its ability to self-correct. Even with the annulment mechanism under the ICSID Convention, its practical functionality is rather limited. Fourth, the appointment of arbitrators under this regime is often made ex post the dispute. When appointing arbitrators, the host state also takes its own interests into account and ignores its public law functions as a sovereign state, which makes the arbitration tribunal lack neutrality in interpreting and applying treaties. Fifth, as the investment arbitration tribunal is not a permanent international organization, huge costs have been involved in maintaining the operation of the whole system. ${ }^{74}$ Sixth, the current ISDS is derived from commercial arbitration which mainly deals with commercial disputes. As a result, the ISDS system does not have appropriate institutional arrangements for the checks and balances of public power so as to ensure transparency and fairness. ${ }^{75}$

Apart from voicing support for the reform of ISDS, the EU believes that the defects exposed by ISDS are no longer suitable for the twenty-first century. ${ }^{76}$ It then proposes to establish an investment court premised on sovereign states as a feasible regime for settling investment disputes. The EU's idea of an investment court directly points to the disadvantages of the current ISDS. First of all, in the scope of actionable disputes, the EU hopes to grant the contracting parties comprehensive rights to regulate in the fields of public safety, environmental protection, consumer rights protection, among others, emphasizing that disputes in these fields can only be resolved through the

73 A. Roberts, Clash of Paradigms: Actors and Analogies Shaping the Investment Treaty System, 107 Am. J. INT'L L. 45-7 (2013).

74 D. Gaukrodger \& K. Gordon, Investor-State Dispute Settlement: A Scoping Paper for the Investment Policy Community 19 (OECD Working Papers on International Investment, 2012).

75 UNCITRAL, Possible Reform of Investor-State Dispute Settlement (ISDS) Submission from the EU, U.N. Doc. A/ CN.9/WG.III/WP.145 (Dec. 12, 2017), at 7-12, https://documents-dds-ny.un.org/doc/UNDOC/LTD/V17/088/32/PDF/ V1708832.pdf?OpenElement.

76 C. Malmstrom, Investments in TTIP and beyond-towards an International Investment Court (May 5, 2015), http://trade. ec.europa.eu/doclib/docs/2015/may/tradoc_153408.PDF. 
contracting parties' own judicial channels. ${ }^{77}$ Moreover, the EU wishes to prevent the arbitration tribunals from interpreting the treaty arbitrarily under the ISDS regime by establishing a political body authorized by the contracting parties to interpret the investment treaties in a uniform manner. ${ }^{78}$ Further, the EU hopes to change the regime of appointing arbitrators by both disputing parties to disputes under ISDS to tenured judges publicly appointed by the investment court so as to strengthen the legitimacy of the dispute settlement mechanism and the effectiveness and consistency of the rulings thereof. ${ }^{79}$ Finally, the EU proposes to change the status quo of the finality of arbitral awards under the ISDS system and to enhance the self-corrective capability of the investment dispute settlement mechanism by setting up a feasible appeal regime. ${ }^{80}$

\section{South-North Divide in the ISDS Reform}

The core design features of BITs and international investment arbitration were to mitigate imbalances between foreign investors and host states, a typical South and North divide, which can destabilize power balances between capital importing and exporting states that the ICSID attempted to achieve. ${ }^{81}$ The ICSID arbitration nevertheless maintains a restrictive policy towards the diplomatic espousal of investment claims by more powerful states, the unexpected consequence of which was to empower foreign investors and create new power imbalances between foreign investors and host states. The side effect of the ISDS system is the over-privatization of ISDS, which can be corrected and rebalanced towards a constructive relationship between foreign investors and host states. ${ }^{82}$

Given this Private-Public divide in nature, ${ }^{83}$ such rebalancing trend is mainly reflected and evidenced by the return of the state movement in which host states, either developed or developing ones, are trying to liberating or restoring their autonomy, authority or state sovereignty by taking these back from the private parties in the ISDS proceedings at least in the field of regulating foreign investment in conformity with their internal police power and public interests. Influenced by this

77 EU Parliament, TTIP: Ease Access to US Market, Protect EU Standards, Reform Dispute Settlement, July 8, 2015, http://documents.nam.org/IEA/EU\%20Parliament\%20Press\%20release\%20July\%202015.pdf.

$78 \mathrm{Id}$.

79 Id.

80 Id.

81 A. Matveev, Investor-state Dispute Settlement: The Evolving Balance between Investor Protection and State Sovereignty, 40 U.W. Austl. L. Rev. 386 (2015-16).

82 S. Puig \& A. Strezhnev, The David Effect and ISDS, 28 Eur. J. InT'L L. 739-42 (2017).

83 L. Trakman, The ICSID under Siege, 45 CORNELl InT'L L. J. 649 (2013). 
Public-Private tension, a pragmatic shift from the ICSID system to domestic courts may be an alternative solution, or a technical response, to the public dissatisfaction with the ISDS (including the ICSID) which has been seen as a sacrifice for more corporate sovereignty. The rebalancing or re-politicization in the spectrum of sovereignty in the ISDS system appears to be for the general good of the world even though it may be labeled as conservative or nationalistic in nature. ${ }^{84}$

In short, facing restrictions on the host state's power exposed in the ICSID arbitration in recent years, whether developing economies withdraw from and evade the ISDS regime or developed economies attempt to reshape the investment dispute settlement mechanism, they all emphasize the due respect for national sovereignty in shaping the investment dispute settlement mechanism. This series of measures is rooted in the sovereignty of all states while nurturing and strengthening sovereignty simultaneously. The trend of the "return" of states at the procedural level of international investment law has already taken shape. ${ }^{85}$ In contrast to the depoliticization process in which the states were leaving their sovereignty with the aim of mitigating the tensions between the North and the South, ${ }^{86}$ the re-politicization movement is an effort to address the distorted tensions between the private and public spheres in international investment.

\section{B. Anti-liberalization Transformation of Foreign Investment Law in the Post-Financial Crisis Era}

\section{Changing Patterns of FDI and FDI Regulation}

The international investment law regime formed on the basis of the "leaving" of states has effectively facilitated the liberalization of global investment and stimulated the economic takeoff of developing states in the 1980s and 1990s. However, along with the in-depth development of international investment in recent years, especially the economic recession in developed states since the latest global financial crisis, the economic gap between the north and the south has been continuously narrowing. Especially, the developing states represented by emerging states are catching up with or even competing with the developed states in FDI, making developed states begin to be on guard. ${ }^{87}$

From a global point of view, the rise of developing or emerging states in the

84 Shan, supra note 1, at 632.

85 I. Odumosu, The Law and Politics of Engaging Resistance in Investment Dispute Settlement, 26 PA. State Int'L L. REv. 257 (2007).

86 Id.

87 UNCTAD, World InVESTMENT Report 2019, at 92-3, https://unctad.org/en/PublicationsLibrary/wir2019_en.pdf. 
field of international investment has deprived developed states of their original dominant position, which leads to a policy transformation of various states tightening up the regulation over foreign capital or investment. ${ }^{88}$ The global financial crisis and the emerging states' rise to be the more important player in FDI have resulted in a sweeping change to the investment-related policies and measures. It has been gradually shifting from the liberalization stance in the 1990s evidenced by deregulation over investment in the context of major liberalization processes, to a restrictive or nationalistic position connecting the dispute settlement back to politics instead of law. Especially before and after the 2008 financial crisis, this policytightening trend became more obvious, and the policy was not relaxed until 2014. Nevertheless, the position of intervention and restriction of foreign investment has not yet returned to the level of the 1990s.

The general trend of anti-liberalization in the field of international investment is embodied in the specific changes in the domestic laws of various states regarding foreign investment supervision policies and the turn of international investment agreements in the direction of treaties. The mode of interaction among stakeholders in investment dispute settlement faces new challenges. ${ }^{89}$

\section{Developed States' Conservative Policy Shift}

Developed states have played a vital role in tightening international investment law in this new anti-globalization or anti-liberalization movement due to the increased regulatory restrictions they imposed on foreign investment. Structural changes in the international investment pattern have made developed states more aware of or even cautious about potential risks that foreign investors may bring into their countries in the fields of science and technology, information, finance, and others. These risks and potential regulatory failures, to a certain extent, forced these states to tackle and resolve the corresponding risks by raising the market access threshold and strengthening regulation over and monitoring of foreign investment activities. ${ }^{90}$

Judging from these regulatory movements, relevant states pay more attention to the supervision of mergers and acquisitions involving foreign investment. In

88 K. Sauvant, W. Maschek \& G. McAllister, Foreign Direct Investment by Emerging Market Multinational Enterprises, the Impact of the Financial Crisis and Recession and Challenges Ahead, at 18 (OECD Global Forum on International Investment, Dec. 8, 2009), http://www.oecd.org/investment/globalforum/44246197.pdf.

89 UNCTAD, WORLd InVESTMENT Report 2010, at 76, https://unctad.org/en/docs/wir2010_en.pdf; WorLd InVESTMENT REPORT 2019, at 84, https://unctad.org/en/PublicationsLibrary/wir2019_en.pdf.

90 UNCTAD, National Security-related Screening Mechanisms for Foreign Investment an Analysis of Recent Policy Developments, Investment Policy Monitor (Dec. 2019), https://unctad.org/en/PublicationsLibrary/diaepcbinf2019d7 en.pdf. 
light of the UNCTAD's observation, in the past few years, quite a number of host governments have frequently opposed the sales of key or strategic domestic assets by domestic enterprises to foreign investors on the grounds of national security. In 2017 alone, at least ten transactions in high-tech manufacturing, financial services or telecommunications industries were canceled for regulatory or political reasons. ${ }^{91}$ Among these transactions, the US and New Zealand are the top two host states of investment, while China is the main home state of investment. According to the data in the first four months of 2018, for a total of seven times, merger and acquisition transactions were put off for national security concerns, primarily in the US. ${ }^{92}$

Since the Trump Administration came into power, it has taken stricter regulatory measures against emerging economies represented by China. The Trump Administration modernized the Committee on Foreign Investment in the United States (CFIUS) review process by passing the Foreign Investment Risk Review Modernization Act (FIRRMA), which was the first update to the CFIUS statute in more than a decade. ${ }^{93}$ The FIRRMA, which came into effect in 2018, comprehensively strengthens the state's right to regulate in the field of foreign investment by expanding the review scope of national security and controlling the sharing of key technologies with emerging economies. The effect of FIRRMA includes potentially longer timelines, the disclosure of more material agreements related to the transaction under review in the notice and mandatory declarations made over whether a transaction is covered or foreign government controlled. ${ }^{94}$

Likely, additional types of Chinese investment would be subject to CFIUS review. The FIRRMA impacts both investments directly by Chinese entities and investments by non-Chinese entities that might have significant ties to China. FIRRMA's key concerns include proximity to sensitive US government facilities, sensitive personal data, critical infrastructure, critical technology, and technology transfer to China. ${ }^{95}$ State-directed and state-funded investment in these areas will be highly scrutinized in particular.

92 Id. at $83-5$

93 F. Jalinous, K. Mildorf \& K. Schomig, FIRRMA: Proposed CFIUS Legislation Would Bring Significant Changes, White \& Case: Publicationa \& Events (Nov. 7, 2017), https://www.whitecase.com/publications/alert/firrma-proposedcfius-legislation-would-bring-significant-changes.

94 Remarks by President Trump at a Roundtable on the Foreign Investment Risk Review Modernization Act (FIRRMA), Aug. 23, 2018, https://www.whitehouse.gov/briefings-statements/remarks-president-trump-roundtable-foreigninvestment-risk-review-modernization-act-firrma.

95 J. Shields, Smart Machines and Smarter Policy: Foreign Investment Regulation, National Security, and Technology Transfer in the Age of Artificial Intelligence, 51 J. MARSHALl L. REv. 286-7 (2018). 
The FIRRMA does allow for greater information sharing with the US state and local governments and foreign allied governments. CFIUS's formal process for the information sharing reflects a broader US government initiative to assist and incentivize partner countries to strengthen their own investment review mechanisms and pursue reviews of transactions of interest to the US government. ${ }^{96}$ Reforms have recently been enacted, or are being actively considered, in the EU, the UK, Canada, Australia, and Japan, among others, and there is growing awareness and interest in investment-security issues worldwide. The US, EU, and Japan have already agreed to engage in investment security formally with an aim to cooperation, information exchange, and potential coordination. ${ }^{97}$ With respect to specific transactions, the increasingly close collaboration on investment-security matters among governments means that certain transactions could face (somewhat) coordinated review across multiple jurisdictions in the future. The potential harmonization of investment security review processes is an area to watch. ${ }^{98}$

The EU has also stressed the importance of foreign investment monitoring in recent years. Specifically, the EU emphasizes the effective implementation of the existing investment laws in Europe. In the field of energy such as electricity and natural gas, for example, it should strengthen the maintenance of the safety of relevant infrastructure and attach great importance to the integrity of property rights, so as to prevent possible operational risks.

Take another example. In the aviation sector, the legal requirement is that the EU citizens possess absolute control over the equity of such enterprises (over 50\%), and the EU is entitled to terminate this transaction when investment activities lead to the control of aviation enterprises falling into the hands of non-EU citizens. ${ }^{99}$ Similarly, in the exploration and production of hydroxides, the EU also allows member states to refuse citizens of a third state to control related enterprises for reasons of national security. ${ }^{100}$ Moreover, while strengthening law enforcement, the EU hopes to establish

96 Jalinous et al., supra note 93.

97 D. Rand \& S. Tankel, Security Cooperation \& Assistance: Rethinking the Return on Investment, at 6, Aug. 5, 2015, Center for a New American Security (Aug. 2015), https:/www.files.ethz.ch/isn/192879/CNAS\%20Report Security\%20Cooperation_FINAL.pdf.

98 Jalinous et al., supra note 93.

99 Directive (EU) 2016/1148 of the European Parliament and of the Council of 6 July 2016 concerning measures for a high common level of security of network and information systems across the Union, https://eur-lex.europa.eu/legalcontent/EN/TXT/PDF/?uri=CELEX:32016L1148\&rid=1.

100 Directive 94/22/EC of 30 May 1994 on the conditions for granting and using authorization for the prospection, exploration and production of hydrocarbons, https://eur-lex.europa.eu/legal-content/EN/TXT/PDF/?uri=CELEX:31994 L0022\& from $=$ EN. 
effective Foreign Direct Investment Screening Mechanisms (FDISM). ${ }^{101}$

From a policy-oriented perspective, the mechanism will examine direct investment into the EU while taking into consideration of public safety. Also, it hopes to provide a non-exhaustive list to determine which direct investments will affect the EU's public security. This will emphatically prevent foreign State-owned enterprises (SOEs), economic entities that are playing an increasingly vital role in current international investment, ${ }^{102}$ by interfering in the EU's key technologies and information security.

From the perspective of follow-up measures, on the one hand, the EU will formulate more detailed foreign investment supervision rules under FDISM for important strategic areas (such as energy, space, transportation) or assets (technologies and inputs linked with strategic departments, key infrastructure across departments, sensitive data) that may cause problems in areas such as safety and public order, and strengthen data analysis and case screening in evaluation. ${ }^{103}$

On the other hand, the EU will also set up an investment policy coordination group composed of the president of the European Commission and representatives of the member states to discuss and formulate policies on such issues as public safety, environmental protection and fair competition to ensure the effective operation of FDISM. ${ }^{104}$

\section{Shifting Focus from Investor Protection to the Right to Regulate}

Apart from the trend of anti-liberalization evidenced by the legislative and administrative measures of various states, IIAs, as legal instruments directly regulating and promoting foreign investment, have also taken on some new features in recent years. Compared with IIAs signed in the 1990s, those signed or revised in recent years placed more emphasis on the host state's right to regulate, and weakened the constraints of ISDS on the host state's sovereignty. ${ }^{105}$ In terms of the definition of investment, certain specific assets are excluded so as to limit the scope of application of the treaty. The obligations of the host state government are further clarified concerning expropriation and compensation clauses, and the investors'

\footnotetext{
101 EU Commission, Screening of Foreign Direct Investment, https://trade.ec.europa.eu/doclib/press/index.cfm?id=2006.

102 UNCTAD, World InVestment Report 2017, at 30, https://unctad.org/en/PublicationsLibrary/wir2017_en.pdf.

103 EU Commission, Welcoming Foreign Direct Investment while Protecting Essential Interests, COM (2017) 494 final, at 5, https://eur-lex.europa.eu/legal-content/EN/TXT/?uri=CELEX\%3A52017DC0494.

104 Id.

105 Xiuyan Fei \& Zhenning Li, Host States' Logic of Balance in Applying the Right to Regulate Foreign Investment Admission, 17 US-China L. Rev 65 (2020).
} 
rights are further clarified with respect to the currency exchange and other issues. ${ }^{106}$ With respect to specific direction, recent IIAs have changed the past mode of focusing solely on the protection of private interests of investors to pay more attention to nontraditional government's right to regulate such as labor treatment, environmental protection, and public safety, highlighting the interests of sovereign states. ${ }^{107}$

The ISDS system has been on a trajectory of re-politicization. ${ }^{108}$ This is the case due to a variety of inherent features of the ISDS system. Although a dispute submitted to the ICSID for arbitration is supposed to be an investment case, the tribunal is often called upon to examine the legality of the host state's policies and regulation, which, by their nature are political. The adjudication of investment disputes has a great regulatory chill on future policy-making and legislative activities involving the host state's public interest. ${ }^{109}$

As a leading country in making the "leaving" gesture and pushing forward the liberalization of international investment, the US shows a conceptual transformation in drafting a treaty when facing changes in the foreign investment patterns since the beginning of the twenty-first century. As early as 2004, the US model BIT underwent a shift from emphasizing the protection of investors to more respect of the right to regulate of sovereign states in terms of public safety and labor treatment. ${ }^{110}$ Generally speaking, the model includes the protection of the right to regulate of contracting parties in terms of public safety, environment and labor treatment in the BIT's objectives, while in specific provisions, it emphasizes the power of the host state with regard to environment and labor treatment, ${ }^{111}$ allowing the host state to levy taxes due to the above factors and limiting the scope of application of national treatment and MFN treatment. At the same time, it values the role of local relief measures in the host state in settling investment disputes and further restricts the discretion of the investment arbitration tribunal in the legal interpretation linked to the above factors. $^{112}$

When a financial crisis or security interest is at stake, the host state is likely to interfere into so-called internal affairs, in which protection takes precedence over

106 UNCTAD, World InVestment RePort 2018, at 95-6, https://unctad.org/en/PublicationsLibrary/wir2018_en.pdf.

107 Id. at 107-15.

108 C. Titi, Are Investment Tribunals Adjudicating Political Disputes? Some Reflections on the Repoliticization of Investment Disputes and (New) Forms of Diplomatic Protection, 32 J. INT'L L. Arb. 262 (2015).

109 Id.

110 M. Kantor, The New Draft Model U.S. BIT: Noteworthy Developments, 21 J. InT'L L. Arb. 383 (2004).

1112004 Model BIT, arts. 12 \& 13.

112 G. Gagné \& J. Morin, The Evolving American Policy on Investment Protection: Evidence from Recent FTAs and the 2004 Model BIT, 9 J. INT'L L. ARB. 381-2 (2006). 
investment obligations. As a result, these countries also have deep suspicion about global investment rules that are increasingly stacked against their interests. Their skepticism is further complicated by the growing strategic competition for economic dominance by emerging states, typically China and some BRICS states. Following the economic recession in developed states due to the 2008 global financial crisis and the rapid economic growth in emerging states the economic gap has been narrowed between the North and the South once again, thereby arousing the vigilance of developed states and intensifying their sovereign supervision over foreign investment, including investment originating from emerging economies. ${ }^{113}$

Although Trump announced the US's withdrawal from TPP after taking office, the consensus reached by Pacific Rim states under the TPP framework still exerts an impact on reshaping the current international economic governance regime. For instance, СРTPP stipulates the non-traditional right to regulate of the contracting parties while inheriting TPP. On the one hand, the investment chapter of the CPTPP emphasizes that the investment activities carried out by investors in contracting parties shall conform to the laws and regulations of the host state in the fields of public health, safety, and environment, allowing the host state to exercise right to regulate, such as applying expropriation for the above reasons. ${ }^{114}$ On the other hand, the CРTPP also provides for investment-related matters in the status of SOEs, labor treatment, environmental protection, non-market economy and competition policies through special chapters. It further ensures the consistency of the protection standards of contracting parties in the above-mentioned fields, thereby facilitating the upgrade to higher standards in relevant international economic activities including investment. ${ }^{115}$

Considering the development of investment supervision policies in states represented by the US and the EU, the protection of investors' rights in developed economies is increasingly giving way to expanding the host state's right to regulate, while the government has taken increasing initiative in investment supervision. ${ }^{116}$ Those developed states who used to rely on the "leaving" of the state to push forward the shaping of the modern international investment law regime have "rebelled" and

113 Wei Shen, Recent Evolution of International Financial Governance System and International Economic Order under the Background of Anti-Globalization: the New Institutionalism Represented by the G20 and the B\&R [逆全球化背景下 的国际金融治理体系和国际经济秩序新近演化一以二十国集团和 “一带一路” 为代表的新制度主义], 187 CONTEMP. L. REV. [当 代法学] 44 (2018).

114 CPTPP arts. 9.2, 9.10, 9.16 \& annex 9-B.

115 D. Desierto, ASEAN Investment Treaties, RCEP, and CPTPP: Regional Strategies, Norms, Institutions, and Politics, 27 WASH. INT'L L. J. 405-6 (2018).

116 UNCTAD, World INVESTMENT RePORT 2020, at 115, https://unctad.org/system/files/official-document/wir2020_en.pdf. 
further affected the formulation of investment policies of developing states. Here, the "return" of the state has turned into a reality in neo-international investment law. In this round of "return" of states, the governments of various states have also paid more attention to the protection of the right to regulate in the fields of, inter alia, labor treatment, environmental and health protection, the status of SOEs, industrial policies. As a matter of fact, the scope of the modern international investment law regime focusing on the protection of investors' interests has been expanded further, highlighting the status of the overall interests of states in the entire governance regime. There emerged a new trend of re-politicization, a novel movement in international investment law when disputes come to some sensitive public policy issues. ${ }^{117}$

The re-politicization movement is harder to define or characterize than the past politicization in the sense that the state is engaged in diplomatic protection through some legal means but clearly with political intentions or agendas. ${ }^{118}$ The "return" of the state in ISDS and the international investment law re-introduces politics, if not nationalistic centralism, and re-expands regulatory space in a politically-charged legal order. Due to the "return" of the state trend, the protection of aliens may be witnessing a resurgence. This is in large part because a number of Global South powers, reconnecting with old patterns, are increasingly wrestling with ideas about how to best protect their diasporas, in a context where territorial human rights remedies may not always be available or adequate. ${ }^{119}$ It is also a reflection of the old Arendtian intuition that to have the backing of a sovereign is a key to protecting one's rights. ${ }^{120}$ Finally, it is a result of the influence of human rights themselves, which increasingly encourage people to expect a certain level of protection from the state in relation to their harm suffered from aboard. International investment law still concerns with how to protect a state's nationals abroad. ${ }^{121}$

\footnotetext{
117 A. Tita, Investment Insurance in International Law: A Restatement on the Regime of Foreign Investment, 11 J. W. Inv. \& Trade 655-6 (2010).

118 C. Titi, Are Investment Tribunals Adjudicating Political Disputes? Some Reflections on the Repoliticization of Investment Disputes and (New) Forms of Diplomatic Protection, 32 J. InT'L L. Arb. 286-7 (2015).

119 S. Rolland, The Return of State Remedies in Investor-State Dispute Settlement: Trends in Developing Countries, 49 Loy. U. Chr. L. J. 403 (2017).

120 See generally H. Arendt, The Origins of Totalitarianism (1973).

121 S. Subedi, International Investment Law: Reconciling Policy and Principle 158 (2008).
} 


\section{Conclusion}

This article has attempted to reveal some of the patterns of difference, dominance and disruption that belie state sovereignty and international investment law's proclaimed universality. International investment law suffers from a type of legal schizophrenia. On the one hand, the US, the EU and other developed states have sought since the mid-twentieth century to liberalize global investment law. The resulting BIT-based and ISDS-centered international investment law regime and plethora of BIT networks have successfully broken down barriers to investment and lifted investor protection standards. ${ }^{122}$ On the other hand, alongside those moves, international investment law also has allowed, created or even maintained exceptions to depart from those primary rules in case of national security or other criteria that comprise a risk to host states' economic security. Taken together, these two legal categories seem benign. Currently, the former is being overtaken by the latter. As a result, the world is facing de-globalization as well as legal crisis like uncertainty. ${ }^{123}$

In the leaving-and-return-of-the-state paradigm, the evolution of international investment law has followed a pattern. Following the rapid development of global investment, customary international law, primarily premised upon sovereignty, no longer sufficiently served the interests of states.

Against this background, the number of states have recognized the detrimental effect of over-emphasizing sovereignty in an international investment law regime which hardly maximized the best interests of these states in terms of attracting foreign investment and boosting economic growth. Developed states then were decreasing their adherence to the concept of sovereignty, thereby pushing forward the shaping of the contemporary international investment law regime, focusing more on foreign investment protection. ${ }^{124}$

However, considering the new changing trend in international investment primarily evidenced by the rise of developing and emerging states, the "leaving" of the state (sovereignty), to a certain extent, damages the interest of the capital importing states and casts doubt over the benefits of the states' leaving away from sovereignty. On the one hand, the excessive restrictions imposed by the ISDS system

\footnotetext{
122 J. Salacuse, BIT by BIT: The Growth of Bilateral Investment Treaties and Their Impact on Foreign Investment in Developing Countries, 24 InT'L LAW. 660 (1990).

123 Chen Dongxiao \& Ye Yu, Global Economic Governance: New Challenges and China's Approaches, 63 CHINA INT'L STUD. 7-9 (2017).

124 A. Bjorklund, Reconciling State Sovereignty and Investor Protection in Denial of Justice Claims, 45 VA. J. INT'L L. 836-7 (2004-05).
} 
on the host states breaks the balance between the states and foreign investors. On the other hand, a policy shift to more restrictive regulation after the global financial crisis also turned the regulatory framework of foreign investment to a less liberal one. ${ }^{125}$ Judging from the regulatory movements towards foreign investment in the US, the EU, and other developed countries, there has been a definite return of the state to paying more attention to national security, environmental protection, public health and other concerns with public interests. The "leaving" or "return" of the state paradigm informs and transforms our understanding of sovereignty and role of state in the context of international investment law.

Received: August 1, 2020

Modified: October 1, 2020

Accepted: November 15, 2020

125 J. Commission, The Global Financial Crisis and International Investment Regimes 104 Am. Soc'y InT'L L. Proc. 444 (2010). 
